\title{
Professors' Training in Cardiopulmonary Resuscitation Using Realistic Simulation Evaluation of the Effectiveness*
}

\begin{abstract}
Paula Rossi Baldini ${ }^{1}$, Regimar Carla Machado ${ }^{2}$, Melissa Basseto ${ }^{3}$, Marina Germani Lucas ${ }^{3}$, Isabela Cristina de Oliveira ${ }^{4}$, Hilaine Cristina Batistini ${ }^{4}$, Erika Fonseca ${ }^{5}$, Alessandro Formenton ${ }^{5}$, Andressa Rodrigues de Souza ${ }^{5}$, Eliane da Silva Grazziano ${ }^{6}$
\end{abstract}

\section{Abstract}

Objective: To evaluate the effectiveness of training in cardiopulmonary resuscitation using realistic simulation as a subsidy to plan an emergency training program for healthcare professors.

Methods: Quasi-experimental research, whose intervention was the theoretical and practical training and the outcome was the level of knowledge about the guidelines for cardiopulmonary resuscitation, involving 22 professors of health courses from two universities in São Paulo, Brazil. The tests were applied in different periods to identify changes after training, both in assessing the quality of the used training method, the as the absorption and relevance of the strategy.

Results: There was statistical significance of the success rate between the first and the second tests only in the theoretical training, and this result remained after the practical training and realistic simulation, regardless of the professor's area of expertise. Forty-nine percent $(49 \%)$ of correct answers were found in the pretest before training; $88 \%$, after the theoretical stage and $80 \%$, after the third and final period.

Conclusion: the number of correct answers between the first and second tests increased more significantly and remained in the third test, demonstrating that the strategy of teaching with demonstrative
1 Nursing Student from the Federal University of São Carlos (UFSCar). Fellow PIBIC/CNPq/UFSCar, São Carlos. SP, Brazil

2 Nurse. PhD in Cardiovascular Surgery (UNIFESP, São Paulo); Adjunct Professor, Department of Nursing of the Federal University of São Carlos (UFSCar), São Carlos, SP, Brazil.

3 Nursing Student from the Federal University of São Carlos (UFSCar), São Carlos, SP, Brazil.

4 Nurse. Master's Graduate Program in Nursing at the Federal University of São Carlos (UFSCar). São Carlos, SP, Brazil.

5 Nurse. Research Group's interest in evidence-based health and teaching strategies at the Federal University of São Carlos (UFSCar). São Carlos, SP, Brazil.

6 Nurse. PhD in Nursing (EEUSP, São Paulo).Adjunct Professor, Department of Nursing of the Federal University of São Carlos (UFSCar), São Carlos, SP, Brazil.

*: Extracted from Scientific Initiation Scholarship Program Scientific Initiation (PIBIC) of the National Council of Technological and Scientific Development (CNPq), 2015-2016.

\section{Contact information:}

Regimar Carla Machado.

Address: Federal University of São Carlos. Highway Washington Luís, Km 235. PO Box 676. Zip Code: 13565-905. São Carlos, SP, Brazil. Tel: 55-16-33518334.

” regimarmachado@gmail.com 
lecture and, especially, the practicing stage by using realistic simulations were effective, as the practical stage was carried out after 15 days of theoretical training.

\section{Keywords}

Cardiac Arrest;

Cardiopulmonary Resuscitation;

Simulated Training.

\section{Introduction}

Cardiopulmonary arrest (CPA) leads to a sudden and unexpected condition of absolute deficiency of tissue oxygenation, either circulatory inefficiency or cessation of respiratory activity [1-3], and even in situations of great service to the CPA, time is an important variable, and it is estimated that every minute the individual remains in CPA, $10 \%$ of survival probability is lost [4].

With the progressive increase in the frequency of CPA, there are estimates of around 200,000 CPA cases per year $[2,5-6]$, highlighting the importance of the ability of health professionals or lay people to use properly their knowledge and ability to perform cardiopulmonary resuscitation (CPR) [6-7]. Thus, the basic resuscitation maneuvers are essential to prevent the deterioration of the victim, predominating the maintenance of coronary and cerebral perfusion $[3,8]$.

The guidelines of the American Heart Association (AHA) and European Resuscitation [3, 9] were developed for lay people and healthcare professionals to perform CPR properly [3, 9-10]. In this way, the resuscitation maneuvers are updated every five years so that they can be increasingly effective and simple to perform. Above all, it is necessary that first rescuers are aware of those changes so that the resuscitation is successful $[3,9,11]$.

Given this context, the training strategy using realistic simulation can provide a more consistent learning, compared with lectures, as the simulation provides an environment closer to reality features. The training in simulated environment correlates with greater retention of knowledge and for a longer time, being a participatory teaching strategy in which students not only see what is being taught. Thus, it is possible to minimize complications resulting from inappropriate interventions, increasing the safety of professionals and patients [11, 12].

Along with realistic simulation, the teaching methodology and evaluation characterized as objective structured clinical examination (OSCE) aims to evaluate the competence of the apprentice in defined clinical situations, through a structured instrument in checklist format, which assists the examiner to focus his/her attention on specific skills [11, 13] in order to observe the learner's performance with real or simulated patients, over a set of stations with different specified clinical tasks for each skill [14-15].

Thus, in order to perform CPR maneuvers with excellence and to develop the rescuers' skills properly, it is essential to have continuous training following protocols [3, 9]. We emphasize the importance of this study to evaluate the effectiveness of theoretical and practical training along with realistic simulations in small groups with professors from multidisciplinary areas, as the team should consist of professionals from different areas for patient care in CPA, always seeking the success of the maneuver.

Given the above, the study aimed to evaluate the effectiveness of training in cardiopulmonary resuscitation using realistic simulation as a subsidy for a training program in emergencies regarding health courses for professors.

\section{Methods}

Quasi-experimental research, whose intervention were theoretical and practical trainings, and the outcome was the level of knowledge about the 
guidelines for cardiopulmonary resuscitation with professors in the health area from two Universities of the state of São Paulo. The study protocol was drawn up following the ethical standards for clinical research in humans, according to Resolution 466/12, and submitted to the Research Ethics Committee of one of the Universities, according to the opinion No. CAAE: 42678915.5.0000.550. All participants signed an Informed Consent Form.

The sample was random by inviting professors of the courses of physiotherapy, nursing, gerontology and occupational therapy of one of the universities and from the nursing course of the other university, in order to attend the theoretical and practical trainings and participate in the research. The inclusion criteria were: being a professor at those universities; accepting to participate voluntarily; signing the Informed Consent Form. Exclusion criteria were professors who were on sick leave, maternity leave and/or vacation during the period of data collection; questionnaires with unanswered questions. Thus, the sample consisted of 22 participants.

First, we set up a website containing information on the training and schedule. Research participants had 20 days to conduct the registration and within 24 hours received a confirmation email. The schedule contained availability of vacancies in morning and afternoon shifts, totaling five groups with up to five participants.

Investigations were carried out in a Practice Simulation Unit at one of the universities and divided into two days for each group: one day for the theoretical stage and another day to practice stage using a realistic simulation strategy, from October to December 2015.

The research was divided into three stages: the first stage was the application of the pretest, theoretical training, post-test application I; the second stage involved the practice training of stations in CPR, realistic simulation and OSCE; the third and final stage held the debriefing and application of post-test II.
The applied tests (pre-tests and post-tests) based on the 2015Guidelines of AHA and European Resuscitation [3, 9] containing guidelines for filling, such as not leaving blank questions, fill only one alternative for each question. It consisted of nine sociodemographic questions and 20 questions related to the variables relevant to the subject of study, as recognition of CPA; request for help; triggering the emergency medical service; positioning of the victim and the rescuer; correct sequence of CPR maneuvers; carotid pulse evaluation; compression/ ventilation ratio and proper use of Automated External Defibrillator (AED). Therefore, in the first stage of the study, we applied the pre-test prior to the theoretical training, in order to understand the knowledge of the participants before the training, which should be completed in 30 minutes. The theoretical training lasted four hours, lectures, using slides, statements movies of each maneuver and heart rhythms and practical demonstration of CPR maneuvers, such as chest compression, opening airways, ventilation and handling the AED. After the theoretical explanation, the post-testing was applied, with 30 minutes for filling to evaluate the effectiveness of the theoretical strategy.

After 15 days, the second stage was carried out, initially with a summary of the theoretical stage and then by training stations (chest compression, opening airways, ventilation and handling AED) separately; and later using realistic simulation strategies for the care of CPA, based on scenarios related to the Intensive Care Unit, Basic Health Unit and Emergency Unit, focused on real situations of everyday life. The elaboration of the atmosphere was according to the place where the situation was happening, with the support of appropriate materials and mannequins simulators; the actors were characterized according to the issue, coordinated by the researchers, with a total duration of three hours.

During the simulation, participants were assessed by the OSCE instrument, which allowed evaluating the mastery of skills and performance during the 
tasks to be performed using a checklist addressing the skills to be tested over the steps taken, such as: security local; recognition of CPA; activation of the emergency medical service; compressions; ventilations and handling the AED.

In the third stage, there was the debriefing, a discussion with the research participants, in which they realized which were the failures and clinical skills acquired. At the end of this stage, the post-test II was applied in order to assess knowledge retention.

For each group that participated in the training, questions relating to the study of the subject were the same, but with alternate orders. The aim of the application of the instrument at three different stages was to identify and understand the changes that were occurring, both in assessing the quality of the training method used, as in the absorption and relevance of the strategy used.

The descriptive and exploratory analysis provided a view of the overall behavior of the data set through the use of the Software $R$ and the application of the Wilcoxon test, with the objective of evaluating the existence of differences between the proportion of successes and failures in the stages of pre-test, posttest I and post-test II, showing whether the teaching and training strategies were effective or not.

\section{Results}

Among the 22 professors participating in the research, only 16 participated in the two days of training. (Table 1)

Table 1. Characterization of professors of health sciences of two universities in the interior of São Paulo state. São Carlos, SP. Brazil, 2016.

\begin{tabular}{|l|c|c|}
\multirow{2}{*}{\multicolumn{1}{c|}{ Variable }} & \multicolumn{2}{c|}{$\mathbf{n = 2 2}$} \\
\cline { 2 - 3 } & N & $(\%)$ \\
\hline Sex & & \\
\hline Female & 22 & 100 \\
Male & 0 & 0 \\
\hline No reply & 0 & 0 \\
\hline
\end{tabular}

\begin{tabular}{|l|c|c|}
\multicolumn{1}{l}{ Variable } & \multicolumn{2}{c|}{$\mathbf{n = 2 2}$} \\
\cline { 2 - 3 } & N & (\%) \\
\hline Category & & \\
\hline Gerontology & 1 & 4 \\
\hline Physiotherapy & 4 & 19 \\
\hline Nursing & 16 & 73 \\
\hline T.O. & 1 & 4 \\
\hline Time experience & & \\
\hline 1 to 5 years & 4 & 18 \\
\hline 5 to 10 years & 7 & 32 \\
\hline Over 10 years & 11 & 50 \\
\hline SVB course & & \\
\hline Yes & 11 & 50 \\
\hline No & 11 & 50 \\
\hline Contact frequency & & \\
\hline Sometimes & 10 & 45 \\
\hline Never & 12 & 55 \\
\hline Trained & & \\
\hline Untrained & 6 & 27 \\
\hline Shortly trained & 11 & 50 \\
\hline Trained & 5 & 23 \\
\hline
\end{tabular}

There was a high percentage of success when comparing the three periods in relation to the recognition categories of CPA, CPR maneuvers and use of AEDs (Table 2). Therefore, only a few profes-

Table 2. Knowledge about the service in CPA in BLS for trained rescuers. São Carlos, SP. Brazil, in 2016.

\begin{tabular}{|c|c|c|c|c|c|c|}
\hline \multirow{3}{*}{ Variable } & \multicolumn{2}{|c|}{$n=22$} & \multicolumn{2}{|c|}{$n=22$} & \multicolumn{2}{|c|}{$n=16$} \\
\hline & \multicolumn{2}{|c|}{ Pre-test } & \multicolumn{2}{|c|}{ Post-test I } & \multicolumn{2}{|c|}{ Post-test II } \\
\hline & $\mathrm{N}$ & $\%$ & $\mathrm{~N}$ & $\%$ & $\mathrm{~N}$ & $\%$ \\
\hline $\begin{array}{l}\text { Recognize the } \\
\text { capabilities of BLS }\end{array}$ & 18 & 82 & 22 & 100 & 15 & 68 \\
\hline Recognitionof CPR & 20 & 91 & 19 & 86 & 14 & 64 \\
\hline Victim Positioning & 22 & 100 & 22 & 100 & 15 & 68 \\
\hline Correct sequence CPR & 14 & 64 & 22 & 100 & 15 & 68 \\
\hline $\begin{array}{l}\text { Compression/ } \\
\text { ventilation ratio }\end{array}$ & 12 & 55 & 21 & 95 & 16 & 73 \\
\hline $\begin{array}{l}\text { Hand place in the } \\
\text { victim's chest }\end{array}$ & 2 & 9 & 3 & 14 & 2 & 9 \\
\hline Oxidation & 10 & 45 & 19 & 86 & 16 & 73 \\
\hline Circulation & 17 & 77 & 22 & 100 & 16 & 73 \\
\hline Defibrillation & 11 & 50 & 18 & 82 & 13 & 59 \\
\hline
\end{tabular}


Table 3. Knowledge of the participants related to other cases of BLS as heart rhythms, oxygen and AED. São Carlos, SP. Brazil, in 2016.

\begin{tabular}{|c|c|c|c|c|c|c|}
\hline \multirow{3}{*}{ Variable } & \multirow{2}{*}{\multicolumn{2}{|c|}{$\begin{array}{c}n=22 \\
\text { Pre-test }\end{array}$}} & \multirow{2}{*}{\multicolumn{2}{|c|}{$\begin{array}{c}\mathrm{n}=22 \\
\text { Post-test I }\end{array}$}} & \multirow{2}{*}{\multicolumn{2}{|c|}{$\begin{array}{c}n=16 \\
\text { Post-test II }\end{array}$}} \\
\hline & & & & & & \\
\hline & $\mathrm{N}$ & $\%$ & $\mathrm{~N}$ & $\%$ & $\mathrm{~N}$ & $\%$ \\
\hline Heart rhythms & 15 & 68 & 22 & 100 & 15 & 68 \\
\hline $\begin{array}{l}\text { Non-shockable } \\
\text { rhythms }\end{array}$ & 8 & 36 & 21 & 95 & 15 & 68 \\
\hline $\begin{array}{l}\text { Time interval for } \\
\text { evaluating heart } \\
\text { rhythm }\end{array}$ & 3 & 14 & 19 & 86 & 13 & 59 \\
\hline $\begin{array}{l}\text { Depth of chest } \\
\text { compressions }\end{array}$ & 6 & 27 & 18 & 82 & 12 & 55 \\
\hline $\begin{array}{l}\text { Volume compressions } \\
\text { per minute }\end{array}$ & 11 & 50 & 22 & 100 & 16 & 73 \\
\hline $\begin{array}{l}\text { Oxygenation victim } \\
\text { without trauma }\end{array}$ & 13 & 59 & 19 & 86 & 14 & 64 \\
\hline $\begin{array}{l}\text { Oxygenation victim } \\
\text { with trauma }\end{array}$ & 7 & 32 & 19 & 86 & 13 & 59 \\
\hline $\begin{array}{l}\text { Power AED } \\
\text { monophase }\end{array}$ & 2 & 9 & 19 & 86 & 11 & 50 \\
\hline PowerAEDbiphasic & 3 & 14 & 16 & 73 & 11 & 50 \\
\hline
\end{tabular}

Figure 1: Box plot of the proportion of success in each test. São Carlos, SP. Brazil, in 2016.

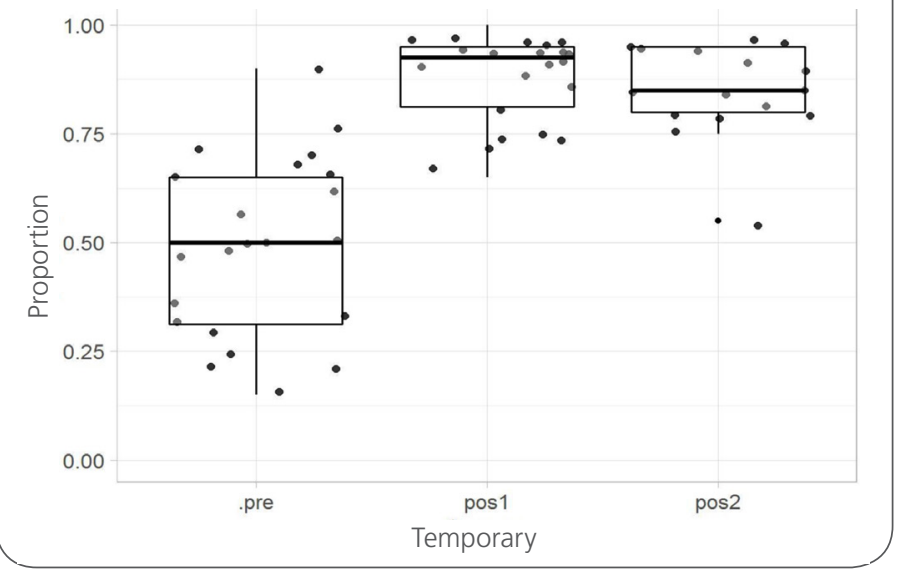

sors recognized the correct location of the positioning of the hands to perform chest compressions. (Table 3)

The Wilcoxon test showed statistically that, after the training, the research participants had a significant increase in the proportion of correct answers in the quiz questions (Pre $\rightarrow$ Post I/Pre $\rightarrow$ Post II) and showed no significant decay over time (Post I $\rightarrow$ Post II), considering that six participants were not present in the day of the research (Figure 1).

\section{Discussion}

Studies aim at the need for continuous updates and training as a form of systematic ongoing education, for both lay people as health care professors, especially those who have more contact with this type of situation, highlighting the rapid identification of CPA, standardization of service and improvement of the performance of the rescuers, continuously, since individuals are subject to deterioration of knowledge, which significantly reduces from six to 12 months after the training [16-17].

The study demonstrated through theoretical tests that knowledge of participants was lower before training. Although 11 (50\%) participants reported having performed some kind of training in BLS, the mean score in the pretest was $49 \%$, rising to $88 \%$ at post-test I, which assesses the effectiveness of lecture with practical demonstrations, videos and performances. In the post-test II, the mean score was $80 \%$, which may be reduced not only by the smaller number of participants, but also by the need for periodic training.

Literature data [1] show there is significant reduction of knowledge in ten weeks, so there must be a constant update to ensure better quality and performance, since the theoretical and practical skills tend to decline over time.

Regarding the qualification, five (23\%) professors considered themselves qualified, 11 (50\%) were poorly qualified, and six (27\%), non-qualified. There were differences in the size of successful answers between the groups: the proportion of correct answers in the group that felt qualified was higher than the proportion of correct answers of other groups in the pretest. Of those, ten (45\%) reported having sporadic contact with situations of CPA and 12 (55\%) reported never having contact. 
Nevertheless, half had already done the course of BLS at some point of their career; however, the increase between the two groups was proportional.

Only ten (45\%) professors indicated having contact with CPA "sometimes"; however, 20 (91\%) knew how to recognize signals in the presence of CPA, even the 17 (73\%) who felt little able or unqualified. Undoubtedly, the quick assistance to a CPA is essential, since the patient's survival depends on rapid identification and agility provided to the victim [4, 18-19].Compared to other studies, most of the participants were able to identify the signs and symptoms of CPA cases [20].

Studies [9, 21-22].emphasize that the diagnostic of CPA should be done quickly and including the evaluation of responsiveness, investigated through tactile and verbal stimulation, ensuring that the victim is able to hear the rescuer; the breathing, observing if the victim has chest expansion, approaching the victim's nose or if the victim is gasping; and the carotid pulse, touching it for about ten seconds. If there is no response, the aid application is necessary, including the application of AED and advanced life support (ALS) $[8,23]$.

In this study, 22 (100\%) research participants correctly identified the position of the victim in the three tests. Regarding the sequence of maneuvers for CPR, only 14 (64\%) correctly identified it in the pretest, compared with another study [1], in which professionals also had difficulty enumerating the correct sequence.

Therefore, the BLS is essential to prevent the deterioration of the victim $[3,9]$, so the guidelines have been developed for health professionals and lay people to perform CPR properly in order to reduce mortality [10].

In the pretest, regarding the understanding of what basic maneuver is the BLS, $18(82 \%)$ correctly reported chest compressions. However, with regard to the correct positioning of the hands on the patient's chest to perform the compressions, only two (9\%) reported correctly; six (27\%) responded correctly the specific depth of compression and 11 (50\%), how many compressions must be provided per minute during CPR. These results are consistent with other studies that have shown that the implementation of those techniques was the biggest deficiency presented by the participants [16].

These results are worrying, since the procedure should be performed properly and effectively, to provide oxygen to the vital organs $[3,9]$.

The compression-ventilation ratio was known by only 12 (55\%) participants, low rate that relates to another study [1], reinforcing the need for periodic training, since the guidelines are constantly updated.

According to the algorithm based on the guidelines in 2015 [3, 9], any treatment served to the victim in CPR associates with the rhythm. However, $15(68 \%)$ correctly reported the patterns of found rhythms; among them, 13 (90\%) defined as having contact "sometimes" with CPA situations, corroborating the study (22) in which the results showed greater accuracy regarding the identification of rhythm with professionals who have contact with this type of emergency where they operate $[3,9]$.

However, the study [17] showed that nurses had difficulties in responding properly to the CPA recognition algorithm. Therefore, it is noteworthy that the justification of the difficulty in recognizing the cardiac rhythm is a need to demand attention for identification [14, 24].

Having as survival after a CPA the interval of time between the event and the start of CPR maneuvers, one way to reduce mortality and provide a good prognosis to the patient is adequate immediate and skilled attention [8, 12]. Literature points out that if the time is less than four minutes, survival rate is $75 \%$; between four and 12 minutes, 15\% and after 15 minutes, only 5\% [16].

The results generally showed low level of correct answers in the pre-test, which may relate to the time when those professors completed college and did not update more on this subject and also to the 
fact that most of them were not working in scenarios that face this kind of situation. As for the decay in the average of correct answers on the post-test II compared to the post-test I, it may be linked to the fact that post-test II have been carried out on the second day of training and six professors did not return to the training, justified by the workload of the training and their available time.

The method used by realistic simulations is useful to evaluate integrated skills of thinking, feeling and acting, enabling better communication competence, execution of procedures under stress conditions and reducing anxiety in performing procedures on real patients.

Associated with the realistic simulation method, the use of the OSCE strategy allowed assessing more accurately the mastery of skills and the performance of each participant after the training, helping to identify the positive aspects and those that can be improved in the proposed training program.

In the debriefing, the research participants reported that, at the time of the simulated service, many conditions were forgotten and were not performed. Thus, they referred to the importance of regular training, in order to be able to perform the entire sequence of service to a CPA without supervision and failures. Those reports corroborate other studies [11, 14, 15-17], in which the participants felt more confident and competent after the realistic simulation and debriefing.

\section{Study limitations}

Although the results obtained from the present study were significant, the reduced number of participants is one of its limitations, as well as the absence of six participants in the post-test phase II. Absences were justified as being due to schedule conflicts with other teaching activities, given that training took place during the semester.

Organizing a training using realistic simulation strategy and the OSCE takes time, mastering the technics and the theme to be worked by the fa- cilitators and assessors involves cost, preparation of the environment and the stages, and requires careful planning schedules, considering that participants are professors of various departments with little flexible hours. However, it was effective for learning skills and competencies in CPR.

\section{Conclusion}

The study found that the training was effective, demonstrating significant increase between the pretest and post-test I, which remained in the post-test II, showing that the teaching strategy with theoretical and demonstrative class, especially the practice stage using realistic simulations, was effective, since the practical stage was carried out 15 days after the theoretical stage, with a significant increase in the percentage of correct answers between the tests.

The assessment of learning through the OSCE allowed to the evaluators to identify more accurately all aspects involved in the simulated service run by the participants, proving to be a useful tool to identify performance in specific clinical tasks.

The data obtained in this study will support the planning of a program for professor training in CPR considering the strengths and weaknesses identified.

Although several studies recognize the importance of training for professionals in health sciences and lay people, it is evident the difficulty to put it into practice, due to the demand of time, effort, cost and the number of people to be trained.

\section{Future research}

For future studies, we suggest the development of a professor-training program in CPR to be performed in periods in which there is no conflict of schedule with other academic activities and with longitudinal assessment, applying the OSCE at intervals of six months. 


\section{References}

1. Almeida AO, Araújo IEM, Dalri MCB, Araujo S. Theoretical knowledge of nurses working in non-hospital urgent and emergency care units concerning cardiopulmonary arrest and resuscitation. Rev Latino-Am Enfermagem 2011; 19(2): 261-268.

2. Brasil. Ministério da Saúde. Portal Brasil. Doenças cardiovasculares causam quase 30\% das mortes no País [updated 2014]. Available from: http://www.brasil.gov.br/saude/2011/09/doencascardiovasculares-causam-quase-30-das-mortes-no-pais.

3. American Heart Association. Destaques da American Heart Association 2015 Atualizações das Diretrizes de RCP e ACE Available from: https://eccguidelines.heart.org/wp-content/ uploads/2015/10/2015-AHA-Guidelines-Highlights-Portuguese. $\underline{\mathrm{pdf}}$

4. Alves FG, Maia LFS. A importância do treinamento em PCR e RCP para os profissionais de enfermagem em unidade de terapia intensiva. Revista Recien. 2011; 1(2):11-16.

5. Brasil Ministério da Saúde. DATASUS. Departamento de Informática do Sistema Único de Saúde. Available from: http:// datasus.saude.gov.br/nucleos-regionais/sao-paulo/noticiassao-paulo/602-dados-do-datasus-demonstram-o-numero-decasos-de-infarto-agudo-do-miocardio-em-sao-paulo

6. Oliveira RG, Favarato MH, Gonzalez MM, Liguori T, Timerman S, Filho RK. Parada Cardiorrespiratória Prolongada Tratada com Sucesso no Metrô de São Paulo. Arq Bras Cardiol. 2014; 102(5):e48-e50.

7. Miotto HC, Camargos FRS, Ribeiro CV, Goulart EMA, Moreira MCV. Efeito na ressuscitação cardiopulmonar utilizando treinamento teórico versus treinamento teórico-Prático. Arq Bras Cardiol 2010; 95(3) : 328-331

8. Nolan JP, Soar J, Cariou A, Cronberg T, Moulaert VRM, Deakin $C D$, et al. European Resuscitation Council and European Society of Intensive Care Medicine Guidelines for Post-resuscitation Care 2015, Section 5 of the European Resuscitation Council Guidelines for Resuscitation 2015. Resuscitation, October 2015, Pages 202-222

9. Perkins GD, Handley AJ, Koster RW, Castrén M, Smyth MA, Olasveengen T, et al. European Resuscitation Council Guidelines for Resuscitation 2015, Section 2. Adult basic life support and automated external defibrillation. Resuscitation, October 2015, Pages 81-99.

10. Boaventura AP, Miyadahira AMK. Programa de capacitação em ressuscitação cardiorrespiratória com uso do desfibrilador externo automático em uma universidade. Rev Gaúcha Enferm. Porto Alegre (RS) 2012 mar; 33(1):191-4.

11. Filho AP, Schmidt A, Filipini C, Castro RBP, Rosa RM, Rosa MAOFR, et al. Simulação de pacientes - cursos de suporte de vida ACLS, BLS e PALS na FMRP - USP. Simpósio: Didática II Simulação; capítulo VIII. 2007; 40(2): 204-12.

12. Flato UAP, Guimarães HP. Educação baseada em simulação em medicina de urgência e emergência: a arte imita a vida. Rev Bras Clin Med. São Paulo. 2011; (5): 360-4.

13. Amaral FTV, Troncon LEA. Participação de Estudantes de Medicina como Avaliadores em Exame Estruturado de Habilidades Clínicas (Osce). Revista Brasileira de Educação Médica. 2007; 31 (1): 81-89.
14. Nulty DD, Mitchell ML, Jeffrey CA, Henderson A, Groves M. Best Practice Guidelines for use of OSCEs: Maximising value for student learning. Nurse Educ Today. 2011 Feb; 31(2):145-51.

15. Zayyan M. Objective Structured Clinical Examination: The Assessment of Choice. Oman Med J. 2011 Jul; 26(4): 219-222.

16. Zanini J, Nascimento ERP, Barra DCC. Parada e Reanimação Cardiorrespiratória: Conhecimentos da Equipe de Enfermagem em Unidade de Terapia Intensiva. Rev. Bras. Terapia Intensiva 2006; 18(2):143-7.

17. Brião RC, Souza EN, Castro RA, Rabelo ER. Estudo de coorte para avaliar o desempenho da equipe de enfermagem em teste teórico, após treinamento em Parada Cardiorrespiratória. Rev Latino-am Enfermagem 2009 janeiro-fevereiro; 17(1)

18. Kern KB, Timerman S, Gonzalez MM, Ramires JA. Optimized approach in cardiocerebral resuscitation. Arq Bras Cardiol 2011; 96(4):e77-e80

19. Atkins DL. Realistic expectations for public access defibrillation programs. Curr Opin Crit Care. 2010 Jun; 16(3):191-5.

20. Garcia SN, Serighelli VF, Quadros VAS. Capacitação dos profissionais de enfermagem para o atendimento ao paciente em parada cardiorrespiratória. Prática Hospitalar. 2009; 11(63)

21. Greif R, Lockeyb AS, Conaghanc P, Lippertd A, Vriese W, Monsieurs KG. European Resuscitation Council Guidelines for Resuscitation 2015 - Section 10. Education and implementation of resuscitation. European Resuscitation Council. Resuscitation 2015; 95: 288-301.

22. Bertoglio VM, Azzolin K, Souza EN, Rabelo ER. Tempo decorrido do treinamento em parada cardiorrespiratória e o impacto no conhecimento teórico de enfermeiros. Rev Gaúcha Enferm. Porto Alegre (RS) 2008 set; 29(3):454-60.

23. Ewy GA, Sanders AB. Alternative approach to improving survival of patients with out-of-hospital primary cardiac arrest. J Am Coll Cardiol. 2013 Jan 15; 61(2):1138.

24. Veiga VC, Carvalho JC, Amaya LEC, Gentile JKA, Rojas SSO. Atuação do Time de Resposta Rápida no processo educativo de atendimento da parada cardiorrespiratória. Rev Bras Clin Med. São Paulo, 2013 jul-set; 11(3):258-62

\section{Publish in International Archives of Medicine}

International Archives of Medicine is an open access journal publishing articles encompassing all aspects of medical science and clinical practice. IAM is considered a megajournal with independent sections on all areas of medicine. IAM is a really international journal with authors and board members from all around the world. The journal is widely indexed and classified Q2 in category Medicine. 